КОНСТИТУЦІЙНЕ ПРАВО; МУНІЦИПАЛЬНЕ ПРАВО

УДК 342.4

DOI https://doi.org/10.32844/2618-1258.2019.5-1.5

БАКУМОВ О.С.

\title{
ІНСТИТУЦАЛІЗАЦЯ ПРАВООХОРОННОЇ ФУНКЦЇ̈ ДЕРЖАВИ ЯК НАПРЯМ ПІДВИЩЕННЯ ВІДПОВІДАЛЬНОСТІ ДЕРЖАВИ ПЕРЕД ЛЮДИНОЮ ТА СУСПІЛЬСТВОМ В УМОВАХ СУЧАСНОЇ УКРАЇНИ
}

\begin{abstract}
У статті показано взаємозв'язок між інституціалізацією правоохоронної функції держави та дією норм інституту юридичної відповідальності держави. Встановлено, що розгляд правоохоронної функції держави та правоохоронних органів тісно пов'язаний із переосмисленням ролі та значення інституту юридичної відповідальності держави. 3'ясовано, що правоохоронна функція держави екзистенційно пов'язана із захистом прав і свобод людини і громадянина, а отже - із інститутом юридичної відповідальності держави. Окреслені основні напрями вдосконалення системи правоохоронних органів України на сучасному етапі проведення конституційної реформи. Наголошено на значимості у забезпеченні дієвості інституту юридичної відповідальності держави громадського (цивільного) контролю за правоохоронними органами держави з боку інституцій громадянського суспільства. Охарактеризована необхідність обов'язковості компенсації заподіяної фізичній особі шкоди, що неодноразово підкреслювалася вищими судовими інстанціями, що сформулювали керівні роз'яснення щодо найбільш складних і важливих питань, які виникають під час розгляду й вирішення справ. Зроблено висновок, що суб'єктом реалізації правоохоронної функції держави є система правоохоронних органів держави, яка в Україні лише частково визначена на конституційному та законодавчому рівнях. Можливість застосування негативної та позитивної юридичної відповідальності держави в діяльності правоохоронних органів $є$ тим більш істотною, чим більш вагомим $\epsilon$ ступінь незалежності системи правоохоронних органів, чим більш урегульованою на рівні спеціальних законів $є$ їх організація та діяльність та чим більше загальний орієнтир діяльності кожного органу матиме більш виражений людиноцентричний характер. Вочевидь, з підвищенням рівня юридичної відповідальності держави пов'язується і конституціалізація правоохоронної функції держави, поступове розширення гарантій належного здійснення правоохоронними органами їхньої діяльності. Водночас законодавча основа їх діяльності має бути приведена у відповідність із вимогами Основного Закону України, а також узгоджена із принципами юридичної відповідальності держави в цілому.

Ключові слова: правоохоронна функиія, правоохоронні органи, система правоохоронних органів, юридична відповідальність держсави, конститучійна реформа.
\end{abstract}

The relationship between the institutionalization of the state law enforcement function and the action of the norms of the state legal responsibility institution was shown in the article. It was proved that the consideration of the law enforcement function of the state and law enforcement agencies is closely related to the re-thinking of the role and significance of the legal liability institution of the state. It was determined that the law enforcement function of the state is existentially connected with the protection of the human

(C) БАКУМОВ О.С. - кандидат юридичних наук, доцент, доцент кафедри конституційного і міжнародного права факультету № 4 (Харківський національний університет внутрішніх справ) 
and civil rights and freedoms, and, consequently, with the legal liability institution of the state. The main directions of improving of the law enforcement system of Ukraine at the present stage of constitutional reform are emphasized in the manuscript. The importance of ensuring the effectiveness of the institute of legal responsibility of the state of public (civil) control over law enforcement bodies of the state by the institutions of civil society is emphasized. The necessity of compensation for the damage caused to an individual is characterized by the need to be repeatedly emphasized by the higher judicial bodies, which formulated guidance on the most complex and important issues that arise in the consideration and resolution of cases. It is concluded that the subject of implementation of the law enforcement function of the state is the system of law enforcement agencies of the state, which in Ukraine is only partially defined at the constitutional and legislative levels. Possibilities of applying the negative and positive legal responsibility of the state in the activities of law enforcement agencies are the more significant, the more important is the degree of independence of the law enforcement agencies, the more regulated at the level of special laws their organization and activity are and the more the general orientation of the activity of each body will be more pronounced. human-centric nature. Obviously, with the increase of the level of legal responsibility of the state is connected with the constitutionalization of the law enforcement function of the state, the gradual expansion of guarantees of the proper implementation by the law enforcement bodies of their activity. At the same time, the legislative basis of their activity must be aligned with the requirements of the Basic Law of Ukraine, and also consistent with the principles of legal responsibility of the state as a whole.

Key words: law enforcement function, law enforcement agencies, law enforcement system, legal liability of the state, constitutional reform.

Вступ. За умов демократизації державно-політичних відносин владарювання, які, як відомо, становлять квінтесенцію конституційно-правових, першочергового значення набуває виконання державою функції охорони права, або правоохоронної функції. Тому невипадково уже декілька років поспіль питання конституційної модернізації правоохоронних органів органічно «вписується» у проблематику конституційного реформування.

Щоправда, останнім часом «градус уваги» до проблеми модернізації конституційно-правових засад правоохоронної функції держави та, відповідно, системи правоохоронних органів дещо знизився - особливо на тлі активної законодавчої діяльності держави у цій сфері, помітної з 2014 року (йдеться як про грунтовну інституційну «добудову» системи правоохоронних органів держави за рахунок включення до неї Національної поліції України, Національного антикорупційного бюро (далі - НАБУ), Спеціалізованої антикорупційної прокуратури (далі - САП), Державного бюро розслідувань (далі - ДБР), Бюро фінансових розслідувань (далі - БФР), так і про функціональні зміни у правоохоронній системі, що особливо помітно в реформуванні органів прокуратури, митних та податкових органів тощо). Водночас у деяких фундаментальних наукових дослідженнях, які грунтують свій дискурс на ключових питаннях конституційної реформи, трансформації правоохоронної діяльності взагалі не знаходиться місця, що, на наш погляд, істотно спрощує розуміння об'єкта та предмету конституційного реформування системи державної влади загалом.

Стан наукового дослідження. Феномен правоохоронної діяльності має соціальний характер, що пов'язується із активним впливом уповноважених суб'єктів на деструктивні внутрішні та зовнішні фактори з метою убезпечення суспільства та гарантування балансу різновекторних (антагоністичних) інтересів. Саме за допомогою правоохоронної діяльності як певної системи інституцій та засобів можливо надати суспільним відносинам ознак стабільності, послідовності, динаміки та розвитку.

Проблематика здійснення правоохоронної функції держави була предметом дослідження О.В. Вакарової, яка наголошувала на тому, що «сучасний етап державотворення в Україні передбачає реалізацію політики активного реформування державних інститутів, які стосуються безпосереднього виконання правоохоронної функції держави, конституційна реформа у сфері правосуддя, реформа міністерства внутрішніх справ, органів поліції, формування нових інститутів протидії корупції та досудового розслідування, оновлення правової бази сфери забезпечення національної безпеки держави - усі ці заходи більшою чи меншою мірою стосуються органів 
державної влади, які реалізують правоохоронну функцію - правоохоронних органів» [1, с. 181]. Актуальні завдання з вироблення державної стратегії і тактики боротьби зі злочинністю, пошуку принципово нових, нестандартних підходів до організації діяльності правоохоронних органів України стали предметом дослідження і В.О. Гусєвої [2].

У юридичній літературі правоохоронна функція держави також розглядається як іманентна (Д.В. Пожарський), екзистенційна (М.В. Дзевелюк), першорядна (Р.Г. Ботвінов), одна 3 провідних (визначальних) (П.В. Онопенко, Р.Я. Шай) тощо. Водночас за умов правової реформи в нашій країні не можна оминути увагою ії суттєву трансформацію, якій останній часом надано саме конституційного звучання і відповідного значення.

Чи не найчастіше останнім часом її (правоохоронну функцію держави) розглядають у контексті глобалізації (В.А. Миколенко) або ж поступової диверсифікації правоохоронної діяльності (частково ототожнюючи останню із правозахисною діяльністю загалом) до сфери відповідальності інституцій громадянського (у тому числі глобального громадянського суспільства, репрезентованого відповідними правоохоронними, квазіправоохоронними та міжнародними судовими інституціями) суспільства (О.І. Безпалова). Не заперечуючи проти плідності і перспективності такого підходу загалом, зазначимо, що і перспективи внутрішнього розвитку правоохоронної функції, наповнення іiї новим змістом, так би мовити, «із середини», на наш погляд, теж містять значні ресурси для правового оновлення.

Постановка завдання. Мета статті полягає у виявленні взаємозв'язку між реалізацією правоохоронної функції держави та дією норм інституту юридичної відповідальності держави.

Результати дослідження. Істотним складником оновленого юридичного дискурсу постає питання юридичної відповідальності не лише фізичних та юридичних осіб, але і держави. Причому, як слушно наголошують учені, інституціалізація юридичної відповідальності держави суттєво модифікує усталені уявлення про юридичну відповідальність як винятково відповідальність особи перед державою [3].

Згаданий правовий інститут стрімко розвивається як за кордоном, так і в Україні. Навіть більше, стан його розвитку зумовлює його потужну конституціалізацію. Відповідно, розвиваються й уявлення щодо того, які органи державної влади найперше мають бути відповідальними за реалізацію згаданого інституту, за практичне втілення відповідних конституційно-правових норм у життя, у повсякденну практику функціонування державних органів. На наш погляд, враховуючи правоохоронний сегмент державної діяльності, ця місія найбільше є властивою правоохоронним і судовим органам, які, кожен у межах своєї підсистеми, виконують важливі суспільні та державні завдання із захисту прав людини і громадянина та з утвердження юридичної відповідальності держави. Адже в системі захисту прав людини саме інститут юридичної відповідальності держави виступає в ролі гарантії реалістичності реалізації цих прав і свобод [4, с. 569].

Конституційна модернізація правоохоронної системи в Україні має виступати одним із чільних факторів зміцнення інституту юридичної відповідальності держави, утвердження права як екзистенційної сутності правоохоронної діяльності та, відповідно, подолання тенденції, констатованої вітчизняними фахівцями: «в Україні немає практики права як суті правоохоронної системи, а є сегментарні ніші права, які своєю незкоординованістю і брутальністю працюють проти української держави і українського народу» [5]. Йдеться і про остаточну відмову від успадкованої Україною «авторитарної державоцентричної моделі правоохоронних органів, яка була зорієнтована не на служіння суспільству, а на репресивні форми соціального контролю» [6, с. 3].

Фактором, що безпосередньо впливає на сферу юридичної відповідальності держави, $\epsilon$ інституційний бік, що корелює з функціонуванням у державі розлогої системи правоохоронних органів, яка має бути скерована на реалізацію як позитивної, так і негативної юридичної відповідальності держави. Система таких органів покликана бути відносно незалежною як у системі органів виконавчої влади, підсистемою якої вона $\epsilon$, так і від органів законодавчої та судової влади. Як слушно зауважує В.М. Дубінчак, «правоохоронні органи мають і самостійне значення, на що вказують їх наступні особливості: особливий порядок утворення; діяльність у особливій сфері правовідносин; особливі процесуальні основи діяльності; своєрідний юридичний статус прийнятих рішень, що мають форму правозастосовних актів; наявність своєрідної структури; наявність особливих функцій» [7, с. 8-9]. Отже, інституційна довершеність системи правоохоронних органів є важливою запорукою реальності та дієвості інституту позитивної юридичної відповідальності держави загалом. Стосовно цього висхідними засадами такої довершеності вважаємо саме конституційну модель правоохоронних органів. Проте на рівні Основного Закону така система окреслена лише в найзагальніших рисах і не має закінченого вигляду. 
Крім того, стала проявлятися і тенденція недовершеності системи правоохоронних органів у зв'язку із створенням і початком функціонування в системі правоохоронних органів, безпосередньо не передбачених Основним Законом України (ДБР та НАБУ), що порушило питання щодо необхідності конституційного закріплення їх спеціального правового статусу [8, с. 178-180].

3 метою вирішення цієї проблеми 29 серпня 2019 року Президент України подав на розгляд Верховної Ради України проект Закону України «Про внесення змін до статті 106 Конституції України (щодо закріплення повноважень Президента України утворювати незалежні регуляторні органи, Національне антикорупційне бюро України, призначати на посади та звільняти 3 посад Директора Національного антикорупційного бюро України і Директора Державного бюро розслідувань)». Водночас окремі питання усунення неузгодженості між Конституцією та чинними законами про ДБР та НАБУ не буде усунуто, зокрема щодо: 1) доповнення пункту 11-1 статті 106 Конституції положенням, що Президент України здійснює призначення на посади Директора НАБУ, Директора ДБР за результатами конкурсного відбору; 2) доповнення статей 85, 106 Конституції України пунктами щодо повноважень Верховної Ради та Президента відповідно делегувати осіб до складу конкурсних комісій з обрання Директора НАБУ, Директора ДБР; 3) доповнення статей 85, 106 Конституції України пунктами щодо повноважень Верховної Ради та Президента відповідно делегувати осіб до складу комісії з проведення незалежної оцінки (аудиту) діяльності НАБУ; 4) доповнення статті 85 Конституції України пунктом щодо повноважень Верховної Ради звільняти з посади Директора НАБУ з підстав та у порядку, визначених законом. Усі інші колізії між положеннями Конституції України та спеціальними законами щодо діяльності НАБУ та ДБР слід усунути шляхом внесення змін до двох останніх і приведення їх у відповідність до Конституції України [9].

Не менш значимим у сенсі забезпечення дієвості інституту юридичної відповідальності держави є громадський (цивільний) контроль за правоохоронними органами держави з боку інституцій громадянського суспільства. Останнє питання теж має свій законодавчий вимір в Україні, що спирається на динаміку співвідношення держави та громадянського суспільства. У цьому сенсі красномовним прикладом стало визнання підпунктом 1 пункту 3 Розділу VI «Прикінцеві та перехідні положення» Закону України «Про національну безпеку України» від 8 липня 2018 року таким, що втратив чинність Закону України «Про демократичний цивільний контроль над Воєнною організацією і правоохоронними органами держави» від 19 червня 2003 року. Якщо новим Законом України «Про національну безпеку України» врегульовані питання, пов'язані з функціонуванням цивільного контролю у сфері безпеки та оборони держави, то положення, які б стосувалися демократичного контролю у сфері правоохоронної діяльності, відсутні, що суттєво послаблює засади здійснення такого контролю, перетворюючи його на несистематизований та неврегульований на рівні єдиного систематизованого законодавчого акта.

На наш погляд, можна погодитися із висловленою в науковій літературі думкою, що «правоохоронна діяльність спирається на підвалини законності та правопорядку, на реалізацію органами держави і місцевого самоврядування, громадськими об'єднаннями (організаціями) соціальних функцій з охорони прав і свобод людини і громадянина, власності і громадського порядку, конституційного ладу держави від протиправних посягань, попередження злочинів та правопорушень» [10, с. 579]. Водночас засобами правоохоронної діяльності державних органів здійснюється не лише позитивна юридична відповідальність держави, зокрема в частині поновлення порушених прав, профілактики правопорушень тощо, але і притягнення до відповідальності самої держави до відповідальності за правопорушувальну діяльність, здійснювану органами державної влади. При цьому особливо істотною є специфікація відповідальності держави за правопорушувальну діяльність самих правоохоронних органів, що цілковито відображає концепт самообмеження (самозобов'язування) державної влади [11]. У цьому сенсі варто нагадати, що матеріальна та моральна шкода, завдана громадянам незаконними рішеннями, діями чи бездіяльністю органів державної влади, їх посадових і службових осіб під час здійснення ними своїх повноважень, відшкодовується за рахунок держави (стаття 56 Конституції України). Держава відшкодовує матеріальну і моральну шкоду, завдану безпідставним засудженням, в разі скасування вироку суду як неправосудного (частина четверта статті 62 Конституції України). Аналогічні положення щодо відшкодування державою матеріальної чи моральної шкоди, завданої фізичним особам актами і діями, що визнані неконституційними, містяться і в частині третій статті 152 Конституції України [12]. Означені норми здобули свою конкретизацію в низці положень Цивільного кодексу України. Зокрема, встановлено, що шкода, завдана незаконними рішеннями, діями чи бездіяльністю органу, що здійснює оперативно-розшукову діяльність, органу розслідування, 
прокуратури або суду, відшкодовується державою лише у випадках вчинення незаконних дій, вичерпний перелік яких охоплюється частиною першою статті 1176 Цивільного кодексу України, а саме у разі незаконного засудження, незаконного притягнення до кримінальної відповідальності, незаконного застосування запобіжного заходу, незаконного затримання, незаконного накладення адміністративного стягнення у вигляді арешту чи виправних робіт [13]. При цьому шкода, завдана громадянинові внаслідок незаконного засудження, незаконного повідомлення про підозру у вчиненні кримінального правопорушення, незаконного взяття і тримання під вартою, незаконного проведення в ході кримінального провадження обшуку, виїмки, незаконного накладення арешту на майно, незаконного відсторонення від роботи (посади) та інших процесуальних дій, що обмежують права громадян, підлягає відшкодуванню на підставі Закону України «Про порядок відшкодування шкоди, завданої громадянинові незаконними діями органів, що здійснюють оперативно-розшукову діяльність, органів досудового розслідування, прокуратури і суду» [14].

У статті 42 Кримінального процесуального кодексу України, норми якої регулюють статус підозрюваного та обвинуваченого, передбачено, зокрема, право вимагати відшкодування шкоди, завданої незаконними рішеннями, діями чи бездіяльністю органу, що здійснює оперативно-розшукову діяльність, досудове розслідування, прокуратури або суду, в порядку, визначеному законом, а також відновлення репутації, якщо підозра, обвинувачення не виправдалися. У частині 3 статті 43 Кримінального процесуального кодексу вказано, що виправданий має права обвинуваченого, передбачені статтею 42 цього Кодексу, в обсязі, необхідному для захисту на відповідній стадії судового провадження. Права на відшкодування з боку держави шкоди зафіксовано і в главі «Відшкодування (компенсація) шкоди у кримінальному провадженні, цивільний позов» [15].

18 вересня 2018 року Верховна Рада України прийняла Закон «Про внесення змін до деяких законодавчих актів України щодо удосконалення забезпечення дотримання прав учасників кримінального провадження та інших осіб правоохоронними органами під час здійснення досудового розслідування». Так, законом внесено зміни до статті 130 Кримінального процесуального кодексу України, статті 1191 Цивільного кодексу України, статей 2, 4 Закону України «Про порядок відшкодування шкоди, завданої громадянинові незаконними діями органів, що здійснюють оперативно-розшукову діяльність, органів досудового розслідування, прокуратури і суду», якими передбачена можливість держави, у разі відшкодування шкоди, завданої слідчим, прокурором, за рахунок Державного бюджету, застосовувати право зворотної вимоги до винних осіб у разі встановлення в їх діях складу не лише кримінального правопорушення, а й за наявності ознак дисциплінарного проступку за результатами службового розслідування, проведеного на підставі рішення суду, яким задоволено скаргу на рішення, дії чи бездіяльність органу досудового розслідування [16]. Слід звернути увагу, що до певної міри «модельними» в цьому сенсі для законодавця вочевидь стали положення щодо пов'язаності юридичної відповідальності держави із відповідальністю державних службовців, утілені, зокрема, в Законі України «Про державну службу». Так, відповідно до статті 80 цього Закону установлено, що матеріальна та моральна шкода, заподіяна фізичним та юридичним особам незаконними рішеннями, діями чи бездіяльністю державних службовців під час здійснення ними своїх повноважень, відшкодовується за рахунок держави. При цьому держава в особі суб'єкта призначення має право зворотної вимоги (регресу) у розмірі та порядку, визначених законом, до: 1) державного службовця, який заподіяв шкоду; 2) посадової особи (осіб), винної (винних) у незаконному звільненні, відстороненні або переведенні державного службовця чи іншого працівника на іншу посаду, щодо відшкодування матеріальної та моральної шкоди, заподіяної державному органу у зв'язку з оплатою часу вимушеного прогулу або часу виконання нижчеоплачуваної роботи. У разі застосування зворотної вимоги (регресу) державний службовець несе матеріальну відповідальність тільки за шкоду, умисно заподіяну його протиправними діями або бездіяльністю. Згідно зі статтею 81 Закону України «Про державну службу» державний службовець зобов'язаний відшкодувати державі шкоду, заподіяну внаслідок неналежного виконання ним посадових обов'язків. Шкодою, заподіяною державним службовцем державі, $є$ також виплачене державою відшкодування шкоди, заподіяної державним службовцем третій особі внаслідок неналежного виконання ним посадових обов'язків. У разі спільного заподіяння шкоди кількома державними службовцями кожен із них несе відповідальність у розмірі, пропорційному ступеню вини. Під час визначення розміру відшкодування враховуються майнове становище державного службовця, співвідношення розміру заподіяної шкоди до його заробітної плати, ризик виникнення шкоди, досвід державної служби, надані державному службовцю накази (розпорядження), а також інші обставини, у зв'язку з якими повне відшкодування державним службовцем шкоди буде необгрунтованим [17]. 
Щоправда, досі ідентичні положення щодо права регресу щодо відшкодування шкоди прямо не встановлені у кількох профільних законах, присвячених діяльності правоохоронних органів. Зокрема, відповідно до частини третьої статті 19 Закону України «Про Національну поліцію» держава відповідно до закону відшкодовує шкоду, завдану фізичній або юридичній особі рішеннями, дією чи бездіяльністю органу або підрозділу поліції, поліцейським під час здійснення ними своїх повноважень. Згідно з частиною третьою статті 20 Закону України «Про Національне антикорупційне бюро України», у разі порушення працівником НАБУ під час виконання ним своїх службових обов'язків прав чи свобод особи, НАБУ вживає в межах своєї компетенції заходів із поновлення цих прав і свобод, відшкодування завданої матеріальної і моральної шкоди, притягнення винних до юридичної відповідальності [18]. На наш погляд, у цих законодавчих актах вміщено вразливі з точки зору конституційності та правозастосування положення: по-перше, суб'єктом компенсації збитків визнається не держава, а орган державної влади, в якому працює особа, що заподіяла шкоду, а, по-друге, не передбачено права регресної вимоги до такої особи з боку відповідного органу.

Насамкінець хотілося б згадати і про такий прояв відповідальності держави у сфері правоохоронної діяльності, як відповідальність за нерозкриття злочину. Так, відповідно до частини третьої статті 127 Кримінального процесуального кодексу України шкода, завдана потерпілому внаслідок кримінального правопорушення, компенсується йому за рахунок Державного бюджету України у випадках та в порядку, передбачених законом [15]. Проте на цей час такого закону ще не існує в системі законодавства України.

Обов'язковість компенсації заподіяної фізичній особі шкоди неодноразово підкреслювалася вищими судовими інстанціями, що сформулювали керівні роз'яснення щодо найбільш складних і важливих питань, які виникають під час розгляду й вирішення справ цієї категорії. Про це йдеться і в роз'ясненнях, що містяться в постанові Пленуму Верховного Суду України «Про судову практику в справах про відшкодування моральної (немайнової) шкоди» від 31 березня 1995 року, згідно з якими спори про відшкодування заподіяної фізичній чи юридичній особі моральної (немайнової) шкоди розглядаються у випадках, коли право на її відшкодування безпосередньо передбачено нормами Конституції або випливає з іії положень [20]. Відповідно до положень Конституції України відшкодування шкоди, завданої потерпілому внаслідок кримінального правопорушення, здійснюється за рахунок Державного бюджету і виступає важливою гарантією захисту прав і свобод громадян. У разі відшкодування шкоди державою фізичній особі, яка потерпіла від кримінального правопорушення, значення має не будь-яка шкода, яку зазнав потерпілий, а тільки та, що стала наслідком злочинного діяння [21].

Відомо, що згідно зі статтею 1207 Цивільного кодексу України установлено обов'язок держави відшкодувати шкоду, завдану каліцтвом, іншим ушкодженням здоров'я або смертю внаслідок злочину. Зокрема, шкода, завдана каліцтвом, іншим ушкодженням здоров'я або смертю внаслідок злочину, відшкодовується потерпілому або особам, визначеним статтею 1200 цього Кодексу, державою, якщо не встановлено особу, яка вчинила злочин, або якщо вона $\epsilon$ неплатоспроможною. При цьому умови та порядок відшкодування державою шкоди, завданої каліцтвом, іншим ушкодженням здоров'я або смертю, встановлюються законом [13]. Проте ця стаття не поширюється на випадки завдання потерпілому шкоди у разі, якщо злочин не розкритий правоохоронними органами і винна особа не встановлена або встановлена, але знаходиться у розшуку.

Європейською конвенцією про відшкодування збитків жертвам насильницьких злочинів від 24 листопада 1983 року [22], Основними принципами правосуддя для жертв і зловживання владою» від 29 листопада 1985 року [23] та Рекомендаціями Комітету міністрів Ради Європи № R (85) 11 від 28 червня 1985 року [24] державам-членам щодо встановлення потерпілого в рамках кримінального права і процесу встановлено різноманітні умови надання компенсації. По-перше, згідно з Конвенцією компенсаційні схеми повинні встановлювати верхню межу, вище якої, та нижню межу, нижче якої збитки не будуть відшкодовуватися. По-друге, режим відшкодування шкоди може встановити строк, протягом якого приймаються звернення щодо відшкодування. Важливо, щоб таке звернення було подано без зволікань після скоєння злочину для забезпечення можливості надання допомоги потерпілій особі, якщо вона відчуває фізичні чи психічні страждання, а також для встановлення та надання оцінки збиткам. По-третє, відшкодування шкоди може бути зменшено або скасовано з урахуванням фінансового становища заявника. Відповідно, ми поділяємо думку фахівців щодо доцільності якнайшвидшої імплементації до національного законодавства положень вищезгаданої Конвенції [21] та доповнення Кримінального процесуального кодексу України окремим розділом щодо умов та порядку відшкодування державою потер- 
пілим шкоди, завданої злочинними посяганнями (або - як альтернативний варіант - прийняття окремого спеціального закону, проекти якого неодноразово вносилися на розгляд Верховної Ради України кількох попередніх скликань) [25, с. 160-161].

Висновки. Правоохоронна функція держави екзистенційно пов'язана із захистом прав і свобод людини і громадянина, а отже - і з інститутом юридичної відповідальності держави. Суб'єктом реалізації такої функції є система правоохоронних органів держави, яка в Україні лише частково визначена на конституційному та законодавчому рівнях. Можливість застосування негативної та позитивної юридичної відповідальності держави в діяльності правоохоронних органів $\epsilon$ тим більш істотною, чим більш вагомим $є$ ступінь незалежності системи правоохоронних органів, чим більш урегульованою на рівні спеціальних законів $є$ їх організація та діяльність та чим більше загальний орієнтир діяльності кожного органу матиме більш виражений людиноцентричний характер. Вочевидь, з підвищенням рівня юридичної відповідальності держави пов'язується і конституціалізація правоохоронної функції держави, поступове розширення гарантій належного здійснення правоохоронними органами їхньої діяльності. Водночас законодавча основа їх діяльності має бути приведена у відповідність до вимог Основного Закону України, а також узгоджена із принципами юридичної відповідальності держави загалом.

Сучасний етап конституційного реформування правоохоронних органів засвідчує необхідність переходу від екстенсивного способу їх розвитку й удосконалення (шляхом добудови системи таких органів новими інституційними елементами) до інтенсивного, що пов'язується переважно із належним правовим упорядкуванням організації та діяльності як традиційних, так і нових елементів системи таких органів, їх гармонізації в умовах функціонування єдиної правоохоронної системи, врахуванням кращих зразків і стандартів правоохоронної діяльності у сфері застосування положень юридичної відповідальності держави.

\section{Список використаних джерел:}

1. Вакарова О.В. Конституційно-правовий статус правоохоронних органів: сучасні підходи : дис. ... канд. юрид. наук : 12.00.02. Ужгород, 2019. 260 с.

2. Гусєва В.О. Основні напрями регулювання діяльності правоохоронних органів Україні в умовах її реформування. Сталий розвиток 2030 : правова, економічна, сочіальна, екологічна та політична складові : матеріали доповідей Міжнар. міждисципл. конф., Будапешт, Угорщина. Будапешт, 2017. С. 73-76.

3. Пархоменко Н.М. Функції юридичної відповідальності в зв'язку із проблемою відповідальності держави перед собою. Правова держава. 2009. Вип. 20. С. 102-110.

4. Яремчук С. Інститут відповідальності держави перед особою як форма реалізації гарантій прав і свобод людини та громадянина. Вісник Наџіонального університету «Львівська політехніка». Юридичні науки. 2017. № 861. С. 567-573.

5. Голомша М. Екосистема правоохоронних органів України : інституційні умови ефективності модернізації державного функціоналу. LB.ua : веб-сайт. URL: https://ukr.lb.ua/blog/ mykola_golomsha/428704_ekosistema_pravoohoronnih_organiv.html.

$\overline{6}$. Концептуальні підходи до реформування органів внутрішніх справ як складової правоохоронної системи та сектору безпеки і оборони України. Концептуальні підходи до реформування МВС у контексті загальнонаціонального плану реформ : інформ.-аналіт. матеріали до Круглого столу, 16 квіт. 2015 р. Київ, 2015. 56 с. URL: http://www.razumkov.org.ua/upload/przh_ Melnyk militsiya_2015 8 5.pdf.

7. Дубінчак В.М. Правоохоронна діяльність : сутність, суб'єкти, засоби забезпечення (теоретико-правовий аспект) : автореф. дис. ... канд. юрид. наук : 12.00.01. Київ, 2010.21 с.

8. Вакарова О.В. Конституційно-правовий статус правоохоронних органів: сучасні підходи : дис. ... канд. юрид. наук : 12.00.02. Ужгород, 2019. 260 с.

9. Висновок на проект Закону України «Про внесення змін до статті 106 Конституції України (щодо закріплення повноважень Президента України утворювати незалежні регуляторні органи, Національне антикорупційне бюро України, призначати на посади та звільняти з посад Директора Національного антикорупційного бюро України і Директора Державного бюро розслідувань)». URL: http://www.pravo.org.ua/news/20873873-visnovok-na-proekt-zakonu-ukrayinipro-vnesennya-zmin-do-statti-106-konstitutsiyi-ukrayini-schodo. 201014.pdf.

C. $577-583$.

10. Дубінчак В.М. Сутність правоохоронної діяльності. Правова держава. 2007. Вип. 18.

11. Филиппова И.С. Концепции ограничения государственной власти: теоретико-правовое исследование : дис. ... канд. юрид. наук : 12.00.01. Нижний Новгород, 2006. 211 с. 
12. Конституція України : Закон України від 28 червня 1996 року. URL: https://zakon.rada.gov.ua/laws/show/254к/96-вр.

13. Цивільний кодекс України : Закон України від 16 січня 2003 року № 435-IV. URL: https://zakon.rada.gov.ua/laws/show/435-15.

14. Про порядок відшкодування шкоди, завданої громадянинові не закон-ними діями органів, що здійснюють оперативно-розшукову діяльність, органів досудового розслідування, прокуратури і суду : Закон України від 1 грудня 1994 року № 266/94-BP. URL: https://zakon.rada.gov.ua/ laws/show/266/94-вр.

15. Кримінальний процесуальний кодекс України : Закон України від 13 квітня 2012 року № 4651-VI. URL: https://zakon.rada.gov.ua/laws/show/4651-17.

16. Про внесення змін до Кримінального процесуального кодексу України щодо удосконалення забезпечення дотримання прав учасників кримінального провадження та інших осіб правоохоронними органами під час здійснення досудового розслідування : Закон України від 18 вересня 2018 року № 2548-VIII. URL: https://zakon.rada.gov.ua/laws/show/2548-viii.

17. Про державну службу : Закон України від 10 грудня 2015 року № 889-VIII. URL: https://zakon.rada.gov.ua/laws/show/889-19.

18.Про Національне антикорупційне бюро України : Закон України від 14 жовтня 2014 року № 1698-VII/ URL: https://zakon.rada.gov.ua/laws/show/1698-18.

19. Про Державне бюро розслідувань : Закон України від 12 листопада 2015 року № 794VIII. URL: https://zakon.rada.gov.ua/laws/show/794-19.

20. Про судову практику в справах про відшкодування моральної (немайнової) шкоди : постанова Пленуму Верховного Суду України від 31 березня 1995 року № 4 (В ред. 2009 року). URL: http://zakon4.rada.gov.ua/laws/show/v0004700-95.

21. Хмельова Н.А. Умови відшкодування шкоди державою фізичній особі, яка потерпіла від кримінального правопорушення. Теорія і практика правознавства. 2015. Вип. 2. URL: http://nbuv.gov.ua/UJRN/tipp_2015_2_13.

22. Європейська конвенція про відшкодування збитків жертвам насильницьких злочинів : міжнародний документ від 24 листопада 1983 p. URL: http://zakon2.rada.gov.ua/laws/show/994_319.

23. Декларация основных принципов правосудия для жертв преступлений и злоупотребления властью : міжнародний документ від 29 листопада 1985 p. URL : http://zakon1.rada.gov.ua/ laws/show/995_114.

24. Рекомендация R (85) 11 Комитета министров государствам-членам относительно положения потерпевшего в рамках уголовного права и уголовного процесса : міжнародний документ від 28 червня 1985 p. URL : http://www.reyestr.court.gov.ua/Review/26425360.

25. Стєбєлєв А.М. Правове регулювання відшкодування (компенсації) шкоди у кримінальному процесі України : дис. ... канд. юрид. наук : 12.00.06. Харків, 2016. 198 с. 